\title{
Dye Test within Mosul Dam Area
}

\author{
Mohammed Sami Safi ${ }^{1}$, Nadhir Al-Ansari ${ }^{2}$ \\ ${ }^{1}$ State Commission for Dams and Reservoirs, Ministry of Water Resources, Baghdad, Iraq \\ ${ }^{2}$ Lulea University of Technology, Lulea, Sweden \\ Email:m.sami.safi@outlook.com,nadhir.alansari@ltu.se
}

How to cite this paper: Safi, M.S. and Al-Ansari, N. (2021) Dye Test within Mosul Dam Area. Engineering, 13, 267-286. https://doi.org/10.4236/eng.2021.136020

Received: May 12, 2021

Accepted: June 8, 2021

Published: June 11, 2021

Copyright $\odot 2021$ by author(s) and Scientific Research Publishing Inc. This work is licensed under the Creative Commons Attribution International License (CC BY 4.0).

http://creativecommons.org/licenses/by/4.0/

\begin{abstract}
Mosul Dam is located on the River Tigris about $60 \mathrm{~km}$ north of Mosul city in Iraq. The dam is a multipurpose earth fill dam with a storage capacity of 11.11 million cubic meters, which was in operation since 1986. During the first impounding of its reservoir, seepage of water underneath the foundation of dam was noticed due to the desolation of gypsum beds. This raised concern about the stability of the dam and since then grouting operation were carried out. ISIS occupied the dam 8 - 16 August 2014. Grouting operations stopped and number of equipment and buildings were destroyed during that short period. After the defeat of ISIS, the Iraqi Ministry of Water Resources rebuilt and constructed the destroyed parts within the site and a new maintenance operations program was adopted. New training courses for the staff of Mosul Dam were conducted with Trevi Company and US Army Corps of Engineers. In this paper, the dye test is highlighted to monitor the seepage of groundwater within the dam site. It seems that the dam is stable in its present conditions and water level height.
\end{abstract}

\section{Keywords}

Mosul Dam, Dye Test, Seepage, Tigris River, Iraq

\section{Introduction}

Mosul Dam is the biggest dam in Iraq and it is located on the River Tigris about $60 \mathrm{~km}$ northwest Mosul City (Figure 1). This dam is a multipurpose dam for flood prevention, electricity generation and irrigation purposes. Its storage capacity is $11.11 \mathrm{BCM}$ at normal operation level 330 meters above sea level (m.s.l.) (Figure 2) [1]-[11]. The construction of the dam took 5 years where it started on 25 January 1981 and it started operating on 7 July 1986.

The rocks at the dam site are mainly composed of alternating beds of limestone, gypsum and marls of the Euphrates and Fatha Formations ([12]-[23]). 


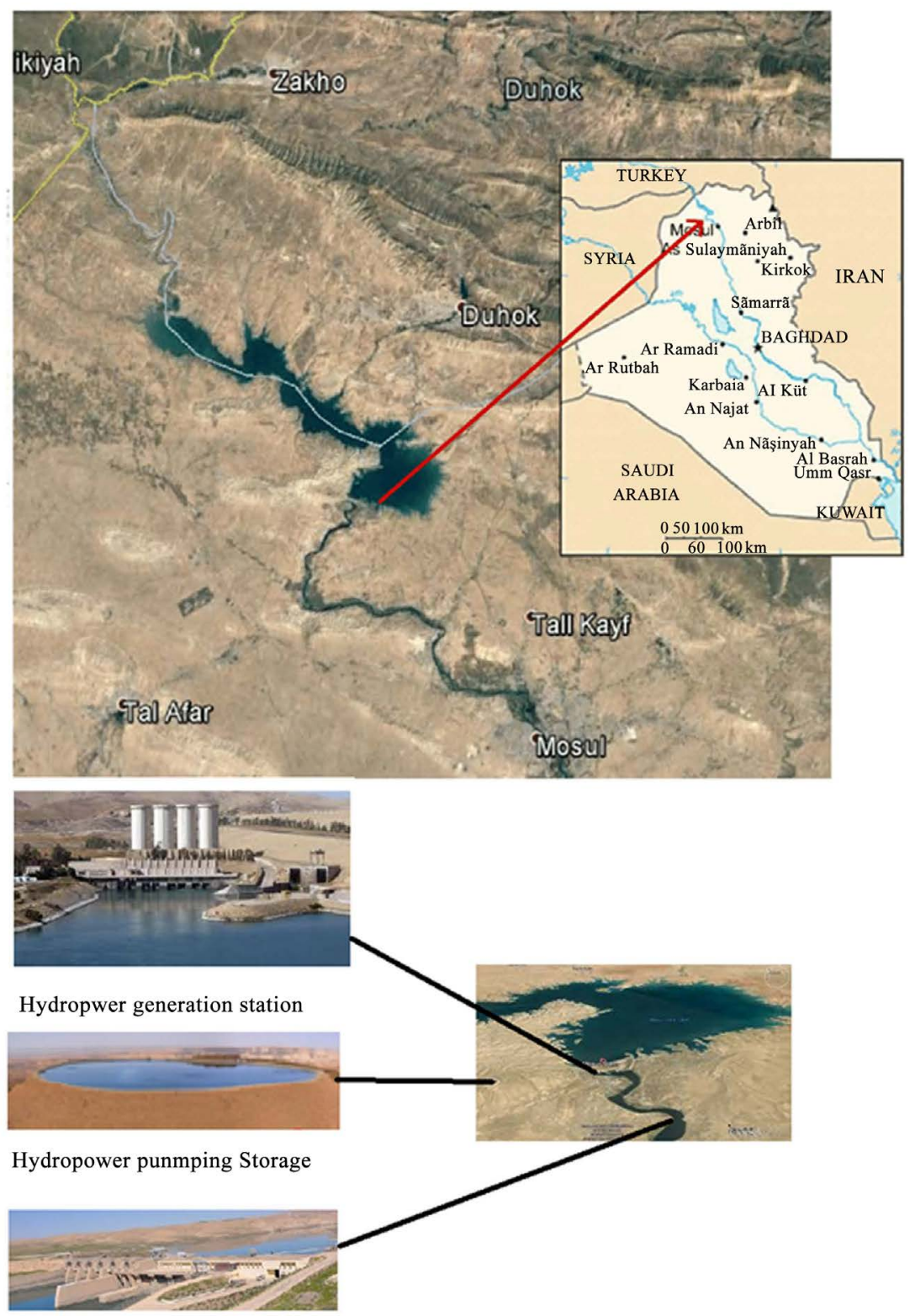

Regulating Dam

Figure 1. Location of Mosul Dam with main facilities.

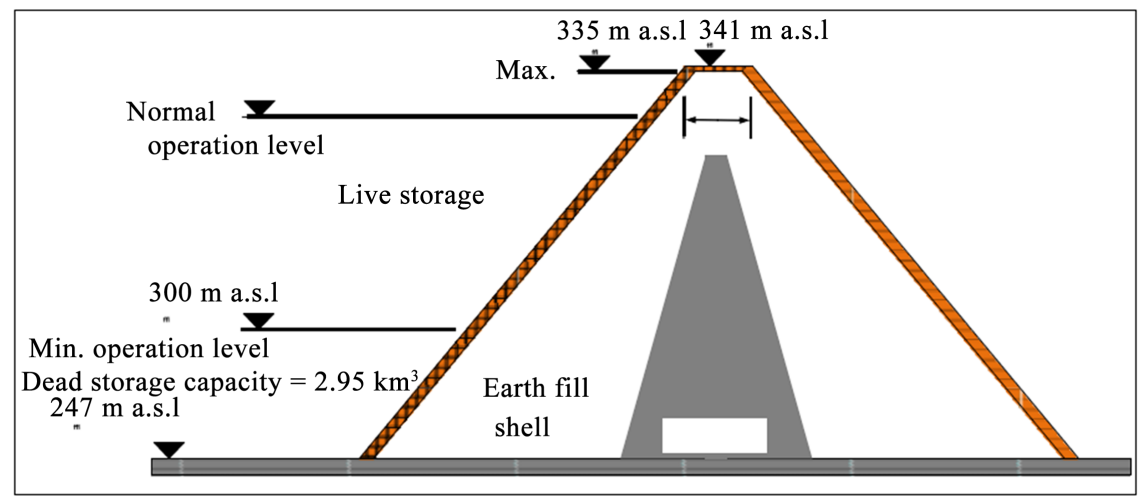

Figure 2. Schematic diagram of Mosul Dam cross section. 
These beds are of cyclic sediments starting with green soft marl, hard limestone and hard gypsum (Figure 3 and Figure 4). Due to their inhomogeneity, their mechanical behavior will certainly behave differently when loaded. The rocks within the dam site are highly karistified and soluble [22]. The karst extends to depths that are about 100 meters below the foundation of the dam (Figure 5) [22]. The nature of these rocks developed number of sinkholes in gypsum and/or limestone [23]-[32]. There are sinkholes downstream of the dam, which developed due to the fluctuations in the tail water level of the main dam during operation of the dam and the down-stream regulating reservoir (Figure 6) [32]. During the construction of the dam, substantial flows were noticed from a gypsum layer found during excavation of the tailrace tunnel for the pumped storage scheme. The seepage water had a high sulphate content, which was different from the reservoir water. The sinkholes are believed to be connected to the aquifer on the right bank of the reservoir. After impounding of the reservoir, new sinkholes developed downstream, the dam and seepages were observed with high sulphide water, which indicates dissolution of the gypsum [22].

After impounding the reservoir in 1986, the impounded water created a new groundwater dynamic that accelerated the dissolution of gypsum under the foundation of the dam and within the reservoir area [22]. This raised concern about the stability of the dam [33] [34] [35] [36] [37]. In view of the conditions, grouting operations were carried out since the start of building the dam to overcome the problem of karstification and jointing of the rocks. The water level was kept not higher than 319 m.a.s.l. International Board of Experts for Mosul Dam [24] [25].

ISIS occupied the dam site 8 - 16 August 2014. They destroyed plenty of the equipment and facilities [22]. All the above events grouting operations were halted which were taking place for more than 30 years. This gave number of researchers that the dam is in critical conditions [38] [39] [40]. After the defeat of ISIS, the Iraqi Ministry of Water Resources rebuilt and constructed the destroyed parts within the site and a new maintenance operations program was adopted [22]. New training courses for the staff of Mosul Dam were conducted with Trevi Company and US Army Corps of Engineers. Now, grouting operations follow very highly upgraded system where new drilling machines and equipment are used now. All the operations are computerized and give accurate information.

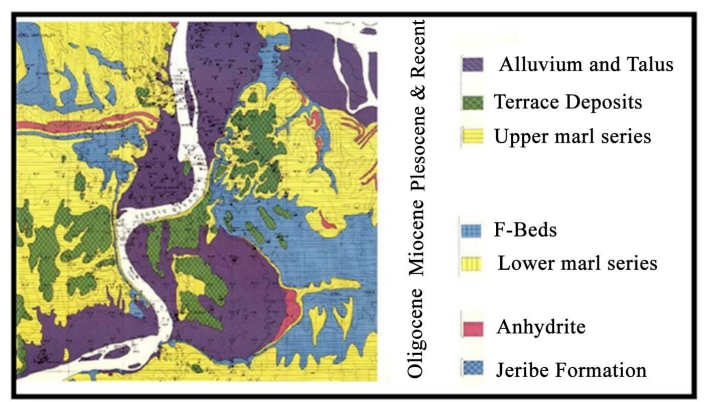

Figure 3. Geologic map of Mosul Dam site area (After [22]). 


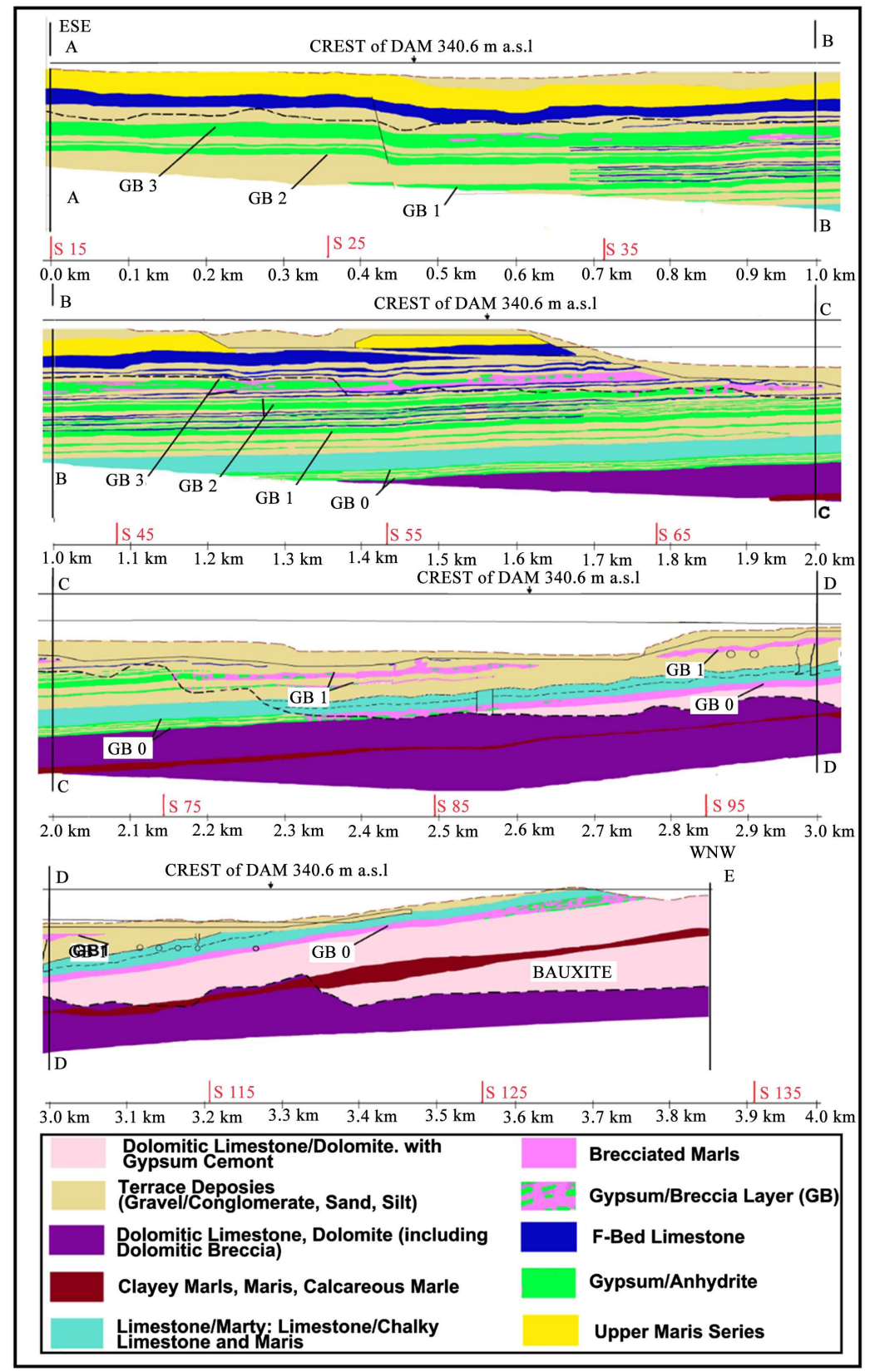

Figure 4. Geologic cross sections along the axis of the dam ([22]).

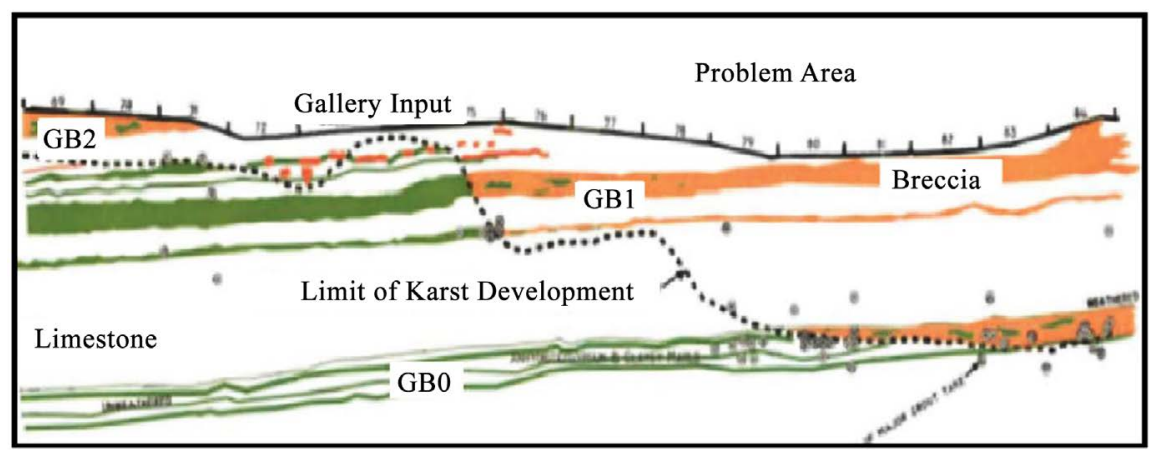

Figure 5. Location of the Karst line. 


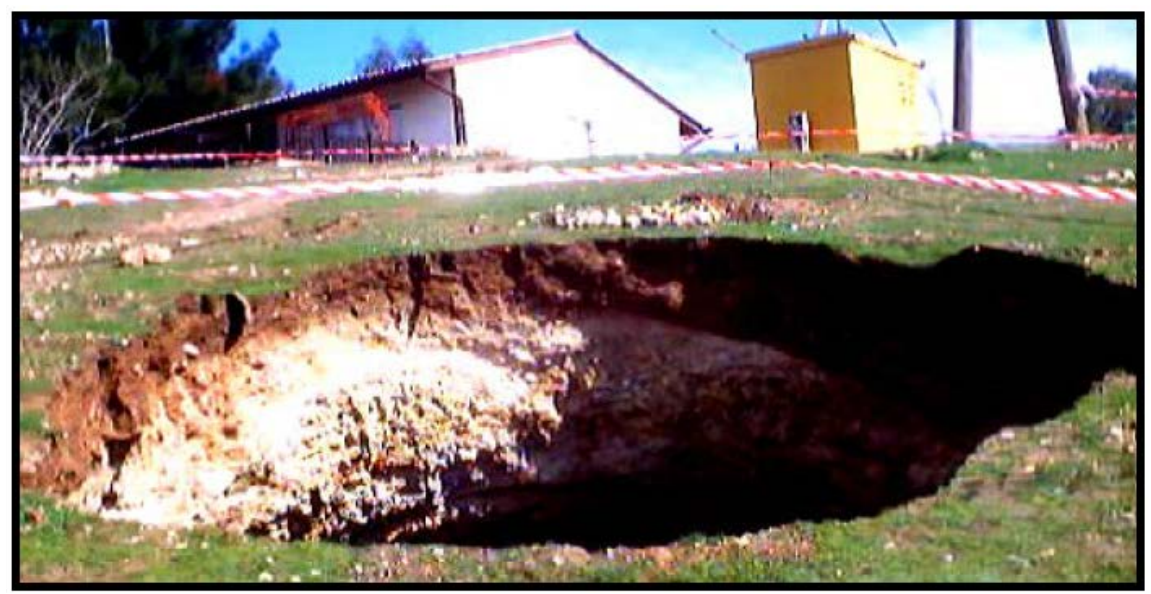

Figure 6. An example of sinkhole that appeared in 2003. The left bank sinkhole after full development.

In this research, one of the ongoing test is discussed. This is the dye test to determine the movement direction of ground water from the area in the left side (east) downstream of the dam. This test gives more accurate and reliable results than other methods using piezometers monitoring. The information using this method gives accurate details of the movement of water through the site.

\section{Methodology}

The dye test was performed to determine the movement direction of ground water from the area in the left side (east) downstream of the dam. In this test, the original ground surface contour lines and subsurface geologic data were used to estimate possible pathway and flow direction. Several points were used to determine potential data collection points (i.e. open hole piezometers, weirs and surface flow points) (Figure 7). For this purpose dye water green colored was injected through the piezometers and/or bore holes that been determined in interval stage or one stage.

\section{Dye Test}

\subsection{Piezometer 18 - 24}

The first dye test at 18 - 24 was conducted on 8 April 2019 in the F-Fed Limestone Aquifer, with the hole open from depth $28.5 \mathrm{~m}$ to $38.0 \mathrm{~m}$. The test was designed to see if a groundwater connection could be confirmed from the east hills to the large water seeps that flow near the spillway (Figure 8). The F-bed Limestone is highly fractured and is known as a good aquifer. Flows from the F-Bed seeps increase with rises in the reservoir pool level, showing that there is some hydrologic connection from the pool. The dye test from $18-24$ was designed to show that the directional flow path of the groundwater in the F-Bed might be in an east-to-west direction in addition to a more direct upstream to downstream direction. After preparing two large water tanks with green dye (Figure 9), the green water was pumped into the F-Bed at 18 - 24 from 11:07 in 


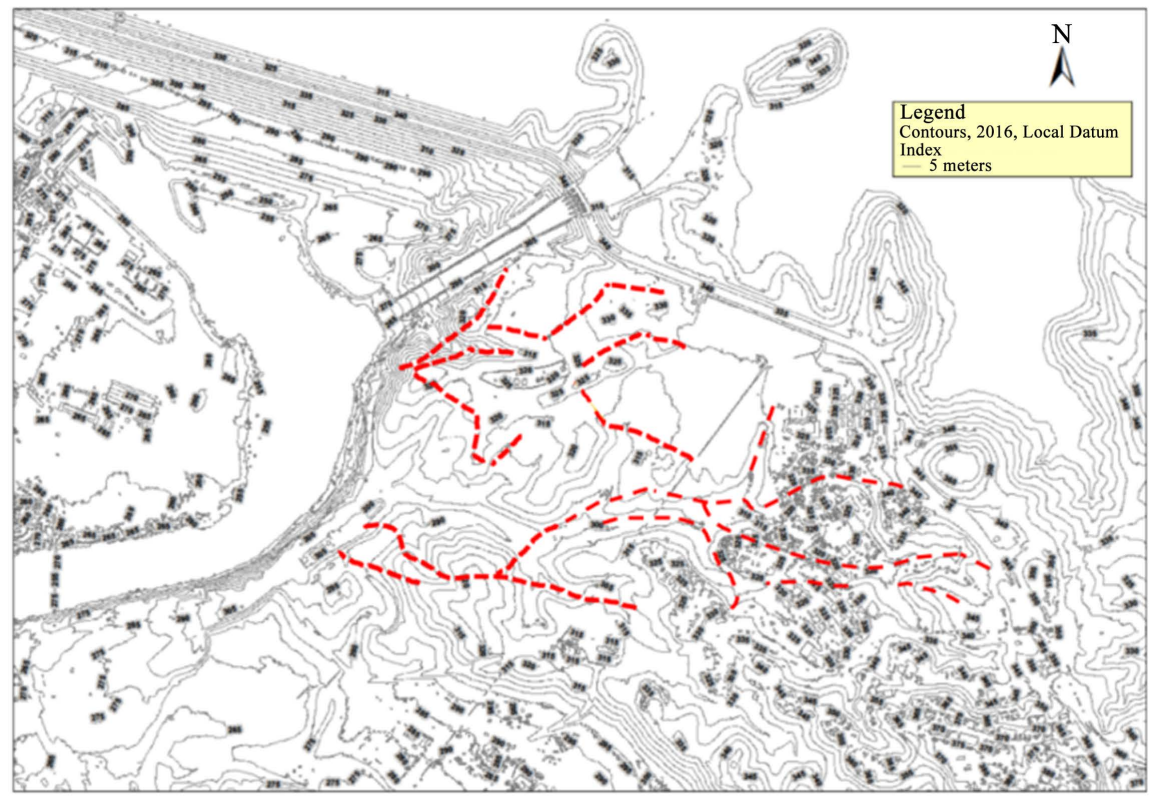

Figure 7. The areas used to determine the potential flow direction.

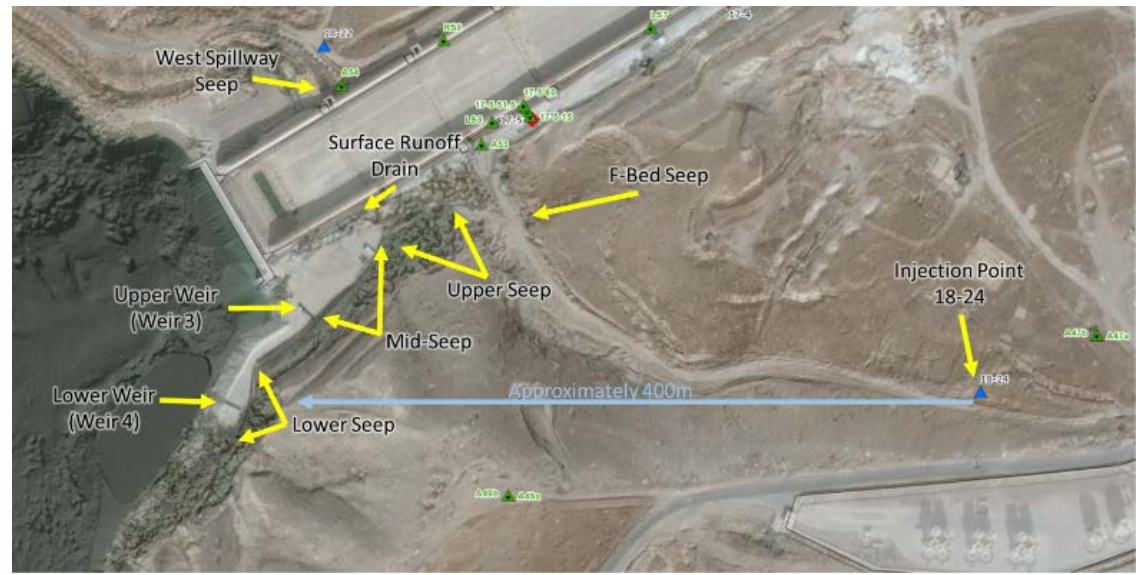

Figure 8. 18 - 24 dye test injection point and observation points.
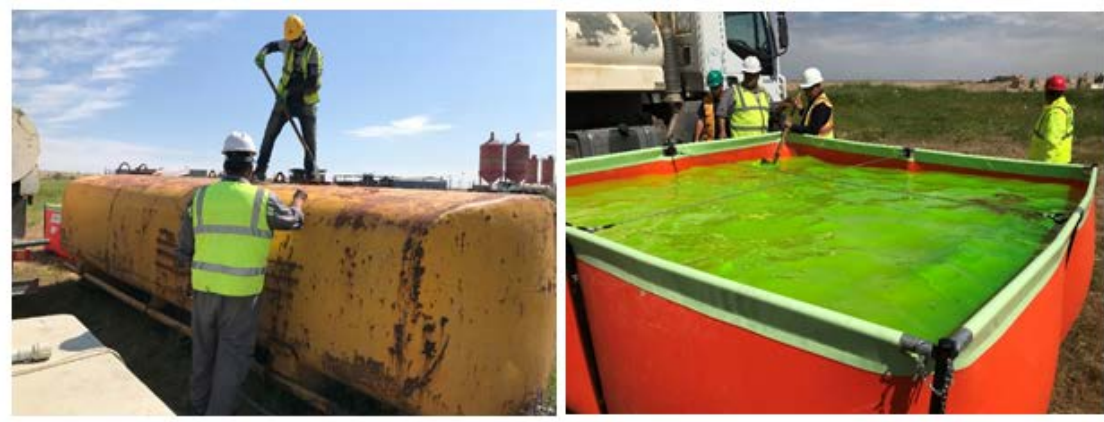

Figure 9. 18 - 24 dye test water tanks being prepared with green dye.

the morning to $15: 17$ in the afternoon, for a total pumping time of 4 hours and 10 minutes. A total of 13,109 liters of dyed water was pumped in the F-Bed Aquifer. The drill team with USACE scientists continuously visually monitored 
the seeps near the spillway from the time pumping started until about 17:00 in the afternoon, but no dye was visually observed (Figure 10).

On 9 April coring continued in 18 - 24 to the base of the LST-2 Limestone in the Lower Marl Series. After collecting flowmeter impeller measurements, the casing was set to leave the hole open from depth $44 \mathrm{~m}$ to $57.5 \mathrm{~m}$ in preparation for the dye test of the Lower Marl Series Aquifer.

Because of the difficulty of seeing the green dye diluted in the larger aquifer, it was suggested that this second dye test use red dye in addition to the green dye. On 10 April a 1 cubic meter container was filled with water, and then mixed with a cement based red dye mix (Figure 11). At 14:17 in the afternoon the 1000 liters of red dyed water was quickly pumped into the Lower Marl Series Aquifer within a few minutes. The red dye was never observed at the seeps.

Another solution to solve the difficulty of visually observing the diluted dye in the seep water was to collect water samples that could later be tested in the water lab for the presence of the dye. On April 10, after the red dye had been pumped into the groundwater, the large tanks of green dye were pumped into the Lower Marl Series Aquifer. Pumping continued for 2 hours from 15:18 to 17:18 in the afternoon. A total of 6359 liters of green water was pumped, but no green dye was visually observed in the seep water. Water samples were collected from the collection points shown in Figure. Control samples were also collected from the dyed water at the injection point.
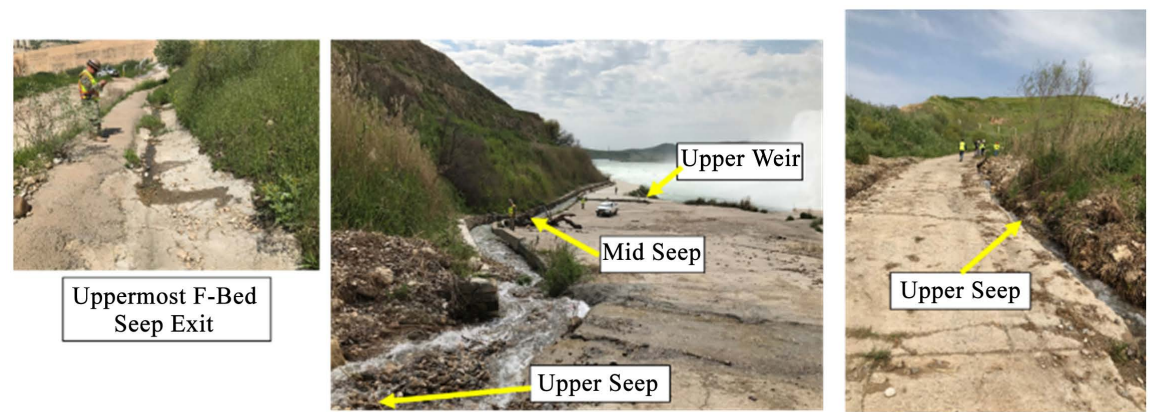

Figure 10. 18 - 24 dye test observation teams looking for green dye.

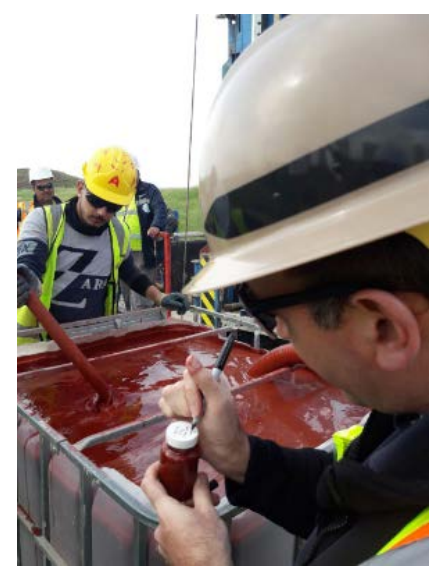

Figure 11. 18 - 24 dye test $1 \mathrm{~m}^{3}$-water tank being prepared with red dye. 
On 11 April, coring continued in exploration hole 18 - 24. Because the dyed green water was still in the water tanks, it was used as a drilling fluid. The tanks were refilled with clean water, so as drilling continued, the drill water became gradually less green. Trevi personnel visited the seep area in the morning and observed no dye in the seep water.

On 12 April in the morning, MoWR personnel visited the seep area and observed green dye in Weir 4 (Figure 12). Additional samples were collected from all the previous collection points. Samples were also collected from one seep from which the dye could visually be seen. It was a large seep above Weir 4 exiting near the top of the LST-2 Limestone in the Lower Marl Series (Figure 13).

On 13 April the dye continued to exit from the main seep above Weir 4, but also was visibly exiting from a seep a couple meters downstream (Figure 14). The second seep was also located near the top of the LST-2 Limestone (Figure 15). No additional samples were collected on 13 April.
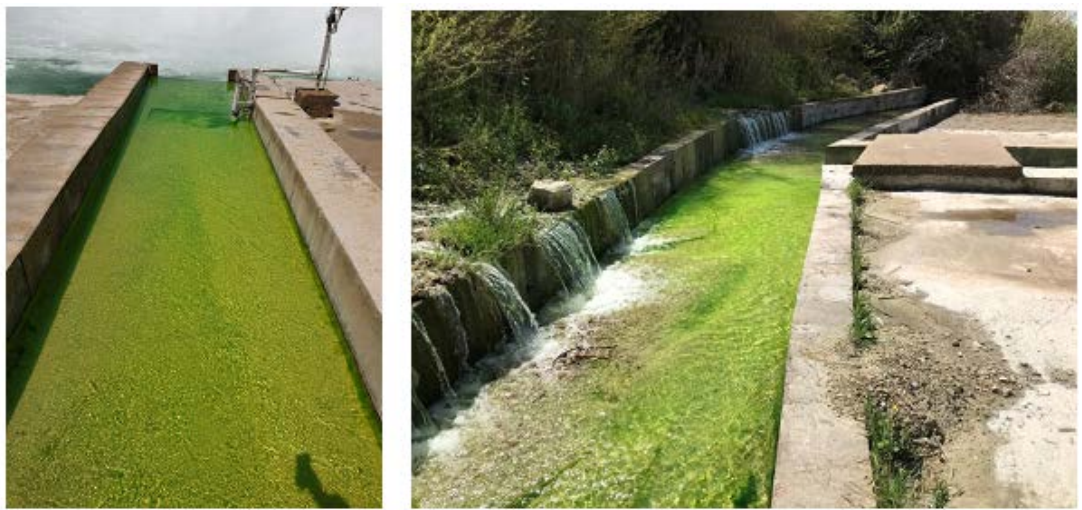

Figure 12. 18 - 24 dye test with green dye observed in Weir 4 on April 12, two days after injection.
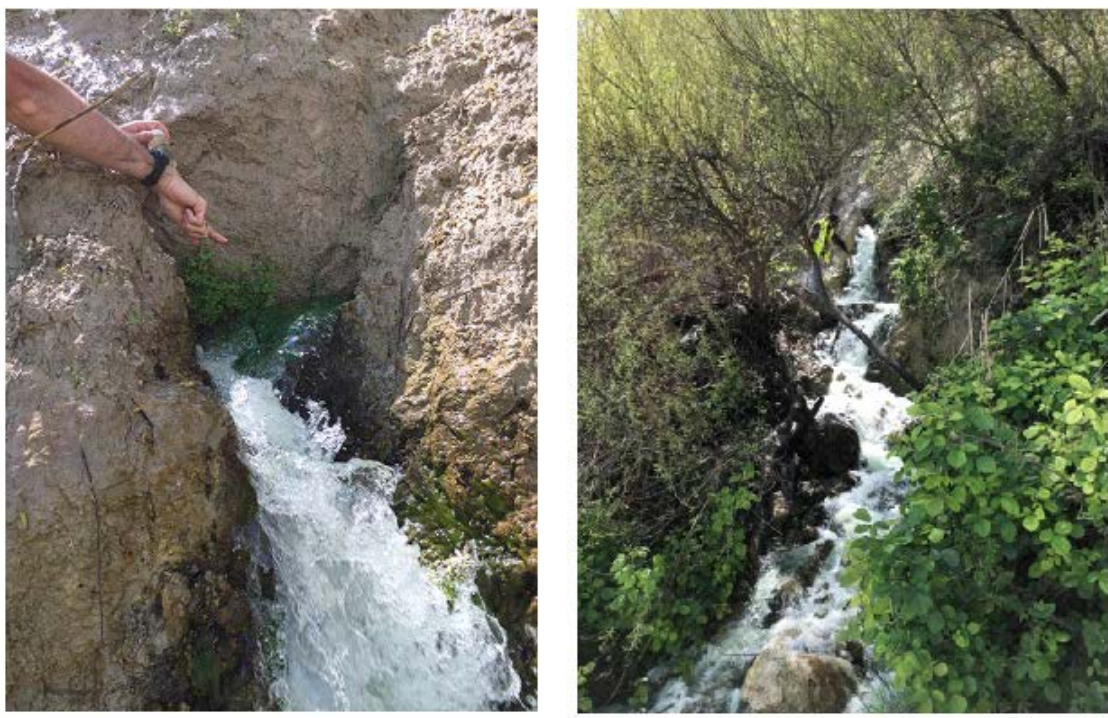

Figure 13. 18 - 24 dye test collecting samples of dyed water from seep above Weir 4 at top of LST-2. 


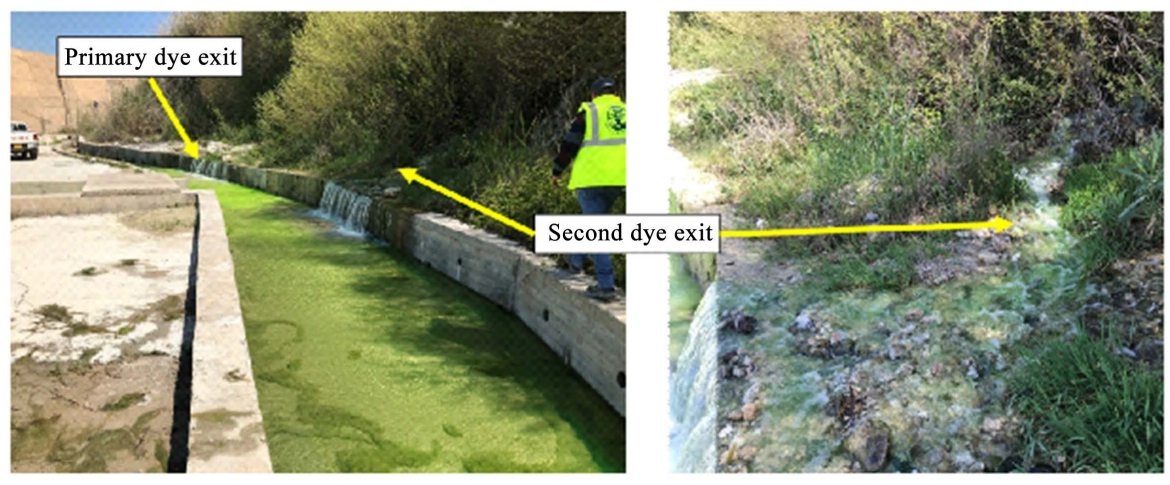

Figure 14. 18 - 24 dye test green dye entering Weir 4 from two separate seeps.
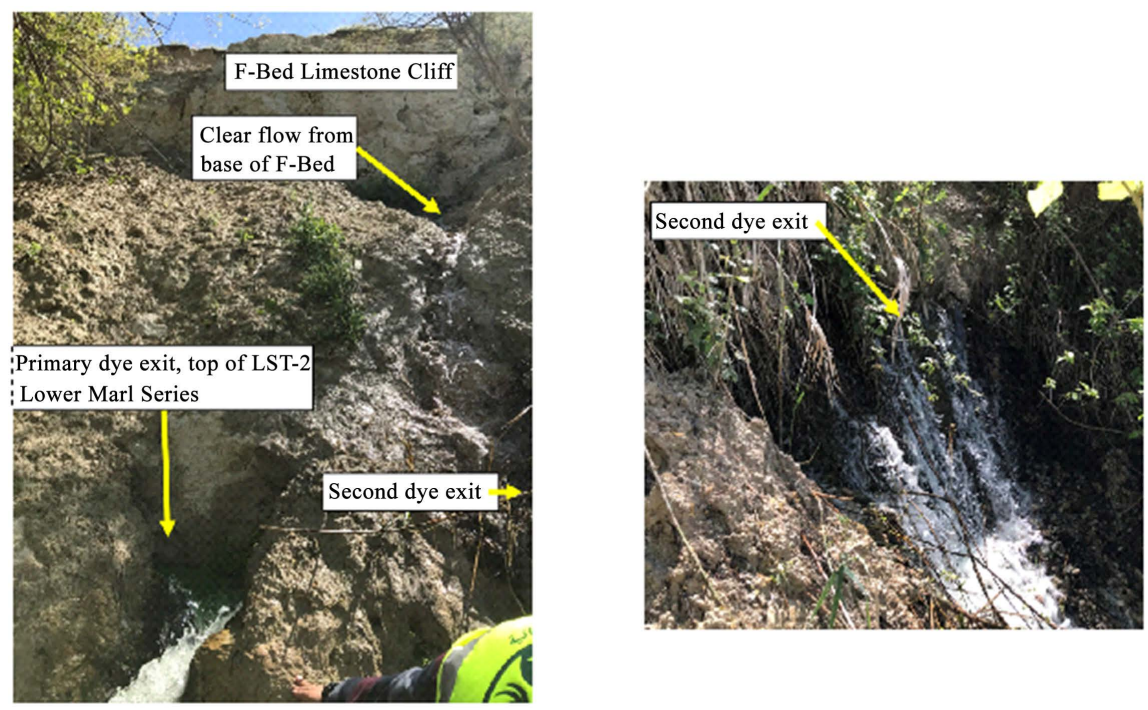

Figure 15. 18 - 24 dye test green dye exiting the LST-2 from two separate seeps.

All of the water samples collected were labeled with the lactation and time of collection, and sent to the water lab to analyze them for the presence of green or red dye (Figure 16). No red dye was detected, but several samples tested positve for the presence of green dye. The machine used to test for the presence of the dye is a 1995 Kontron Instruments SFM 25 Spektrafluorometer (Figure 17). The machine analyzes the wavelength of light passing through the samples with green dye from the injection point, and then compares that wavelength to the collected water samples. The results are shown in Figure 16 and Figure 17 and Table 1.

The results show that both the F-Bed Limestone and Lower Marl Series Aquifers have a component of flow from the east hills to the large seeps near the Spillway. Flowrates through the bedrock were longer than orignally estimated, with the dye taking well over a day to cover the $400 \mathrm{~m}$ distance from 18 - 24 to the seeps. The F-Bed Aquifer has a smaller and slower flow, and potentially took several days to be detected. However, we cannot be certain about F-Bed flowrates since no water samples were collected during the first days of the dye testing. The Upper Seep that flows towards Weir 3 never had any signs of dye, 
Table 1. Dye test results for point $18-24$.

\begin{tabular}{|c|c|c|c|}
\hline Collection Point & $\begin{array}{l}\text { Collection } \\
\text { Date/Time }\end{array}$ & $\begin{array}{l}\text { Sample } \\
\text { ID }\end{array}$ & $\begin{array}{l}\text { Dye Present } \\
(\mathrm{Y} / \mathrm{N})\end{array}$ \\
\hline F-Bed Seep & 10.4.2019 14:50 & FB-1 & $\mathrm{Y}$ \\
\hline F-Bed Seep & $10.4 .201915: 45$ & FM-2 & $\mathrm{Y}$ \\
\hline F-Bed Seep & $10.4 .201916: 35$ & FB-3 & $\mathrm{Y}$ \\
\hline F-Bed Seep & $12.4 .201911: 46$ & FB-4 & $\mathrm{Y}$ \\
\hline Injection point & $10.4 .201914: 13$ & IP-1 & $\mathrm{Y}$ \\
\hline Injection point & 10.4.2019 16:38 & IP-2 & $\mathrm{Y}$ \\
\hline Injection point & 10.4.2019 16:43 & IP-3 & $\mathrm{Y}$ \\
\hline Lower seep & 12.4.2019 11:22 & LS-1 & $\mathrm{Y}$ \\
\hline Lower seep & 12.4.2019 11:25 & LS-2 & $\mathrm{Y}$ \\
\hline Lower seep & $12.4 .201911: 25$ & LS-3 & $\mathrm{Y}$ \\
\hline Lower seep & 12.4.2019 11:28 & LS-4 & $\mathrm{Y}$ \\
\hline Lower seep & 12.4.2019 11:34 & LS-5 & $\mathrm{Y}$ \\
\hline Lower seep & 10.4.2019 14:42 & LW-1 & $\mathrm{N}$ \\
\hline Lower seep & 12.4.2019 11:36 & LW-10 & $\mathrm{Y}$ \\
\hline Lower seep & 10.4.2019 15:01 & LW-2 & $\mathrm{N}$ \\
\hline Lower seep & $10.4 .201915: 24$ & LW-3 & $\mathrm{N}$ \\
\hline Lower seep & 10.4.2019 15:36 & LW-4 & $\mathrm{N}$ \\
\hline Lower seep & 10.4.2019 15:49 & LW-5 & $\mathrm{N}$ \\
\hline Lower seep & $10.4 .201916: 35$ & LW-6 & $\mathrm{N}$ \\
\hline Lower seep & 10.4.2019 17:00 & LW-7 & $\mathrm{N}$ \\
\hline Lower seep & 10.4.2019 17:32 & LW-8 & $\mathrm{N}$ \\
\hline Lower seep & $12.4 .201911: 18$ & LW-9 & $\mathrm{Y}$ \\
\hline Mid seep & 10.4.2019 14:30 & MS-1 & $\mathrm{N}$ \\
\hline Mid seep & $10.4 .201914: 36$ & MS-2 & $\mathrm{N}$ \\
\hline Mid seep & 10.4.2019 14:48 & MS-3 & $\mathrm{N}$ \\
\hline Mid seep & 10.4.2019 16:29 & MS-4 & $\mathrm{N}$ \\
\hline Mid seep & 10.4.2019 17:00 & MS-5 & $\mathrm{Y}$ \\
\hline Mid seep & $10.4 .201917: 31$ & MS-6 & $\mathrm{Y}$ \\
\hline Mid seep & 12.4.2019 11:41 & MS-7 & $\mathrm{N}$ \\
\hline Surface Runoff & 10.4.2019 17.35 & SR-1 & $\mathrm{Y}$ \\
\hline Upper seep & 10.4 .201914 .30 & US-1 & $\mathrm{N}$ \\
\hline Upper seep & 10.4 .201915 .36 & US-10 & $\mathrm{N}$ \\
\hline Upper seep & $10.4 .201915: 48$ & US-11 & $\mathrm{N}$ \\
\hline
\end{tabular}




\section{Continued}

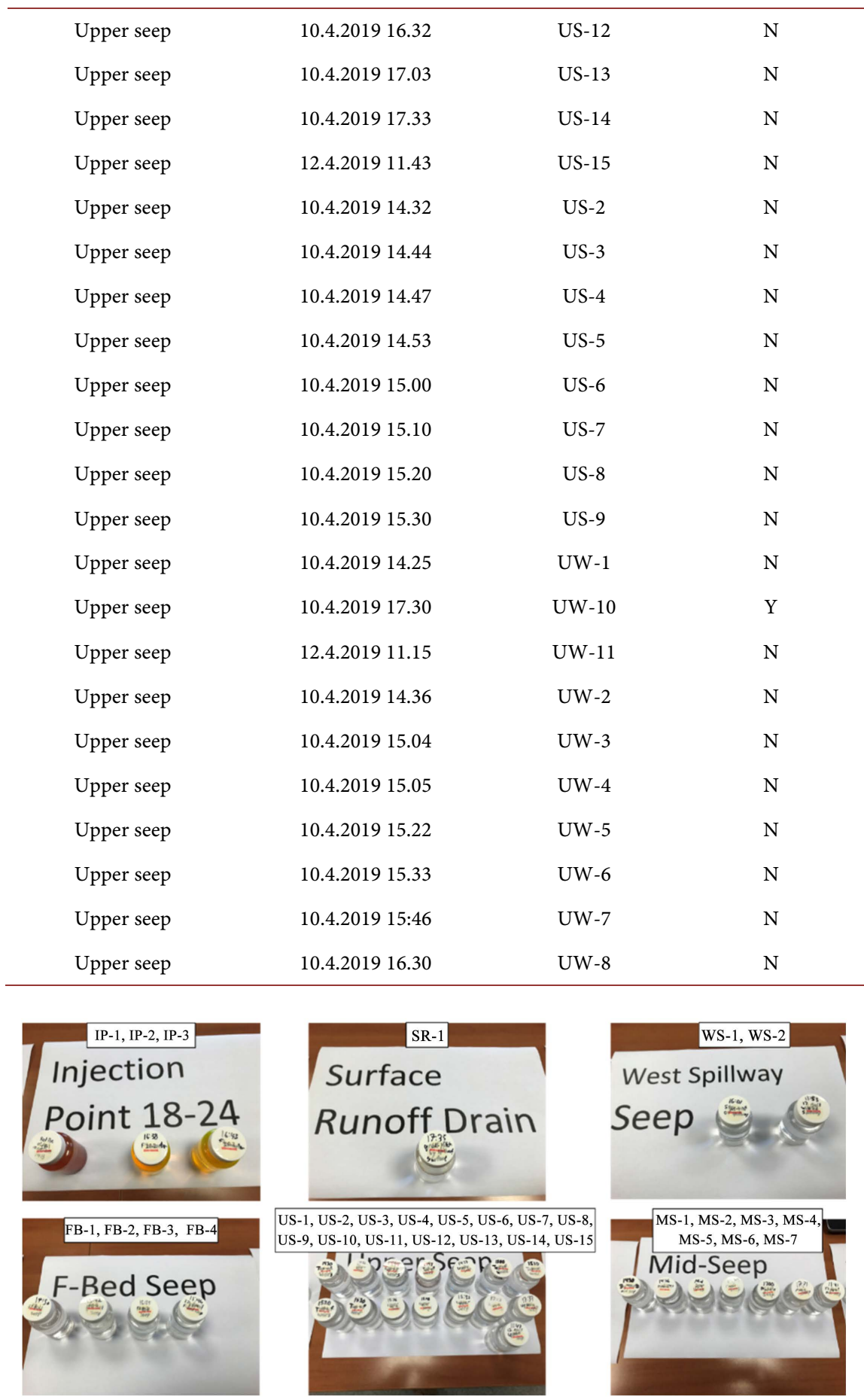

Figure 16. 18 - 24 dye test samples sent to the water lab for analysis of dye.

though the Middle Seep that also flows towards Weir 3 did test positive for dye. The Lower Seep by Weir 4 of course tested positive for dye since it was already visible. Most all the dye exited from seeps near the top of the LST-2 Limestone in the Lower Marl Series. This shows a complex subsurface flow pattern where the dye moved to some select seep exit points, but not others. 


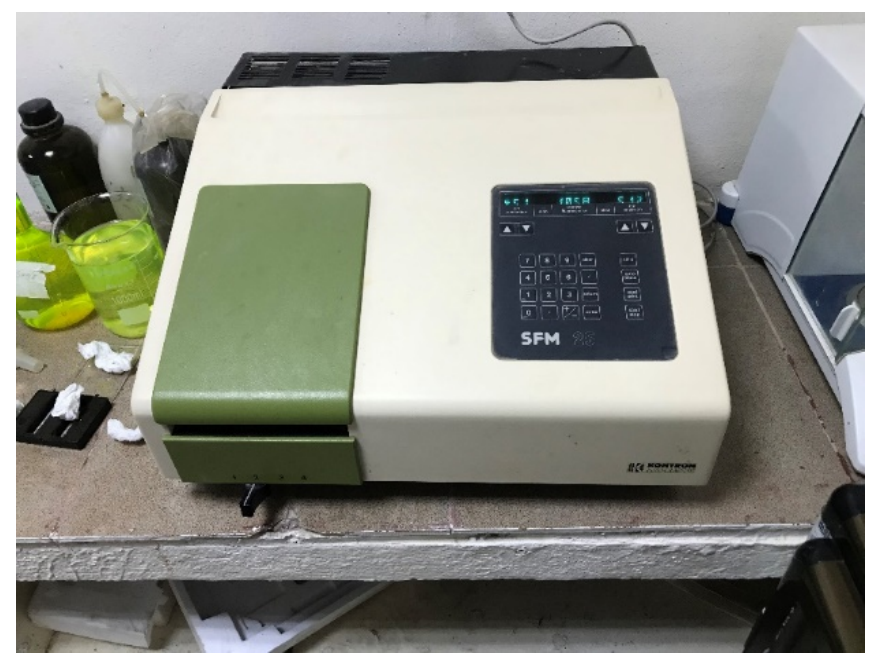

Figure 17. 1995 Kontron instruments SFM 25 Spektrafluorometer in the water lab.

\subsection{Piezometer 19 - 1}

The second dye test at 19 - 1 was conducted on 5 May 2019 in the F-Fed Limestone and Lower Marl Series Aquifer, it's done on 3 steps (stages). With the hole open from depth $40 \mathrm{~m}$ to $60.5 \mathrm{~m}$ this is stage 1 . The test was designed to see if a groundwater connection could be confirmed from, the east hills to the large water seeps that flow near the spillway the area of the saddle dam on the left (east) crest (Figures 18-20).

Stage 2 dye test at 19 - 1 was conducted on 11 May 2019 in the Lower Marl Series Aquifer, with the hole open from depth $60.5 \mathrm{~m}$ to $77 \mathrm{~m}$. The test was designed to see if a groundwater connection could be confirmed from the east hills to the large water seeps that flow near the spillway and the piezometers in the area of the saddle dam on the east crest. The green water was pumped into the Lower Marl series at 19- 1 from 9:15 in the morning to 11:15 in the morning, for a total pumping time of 2 hours (Figure 21). A total of 6000 liters of dyed water was pumped in the F-Bed Aquifer. The results are shown in Table 2.

At stage 3 dye test at 19 - 1 was conducted on 16 May 2019 in both F-Bed and Lower Marl Series Aquifer, with the hole open from depth $40 \mathrm{~m}$ to $77 \mathrm{~m}$. The test was designed to see if the groundwater connection could be confirmed from the east hills to the large water seeps that flow near the spillway and the piezometers in the area of the saddle dam on the east crest.

\subsection{Piezometer 161S-U-P03 Dye Tests}

The dye test at Borehole 161S-U-P03 was conducted on 18 June 2019 in the F-Fed Limestone Aquifer, with the borehole open from depth $31 \mathrm{~m}$ to $40 \mathrm{~m}$. The test was designed to see if the groundwater connection could be confirmed from the east hills of the grout curtain extension to the large water seeps that flow near the spillway, the area of the saddle dam on the left (east) crest. And it's been agreed to do this test after hearing a very high flow of water during the activity of the drilling and grouting in this hole (Figure 22 and Figure 23). 


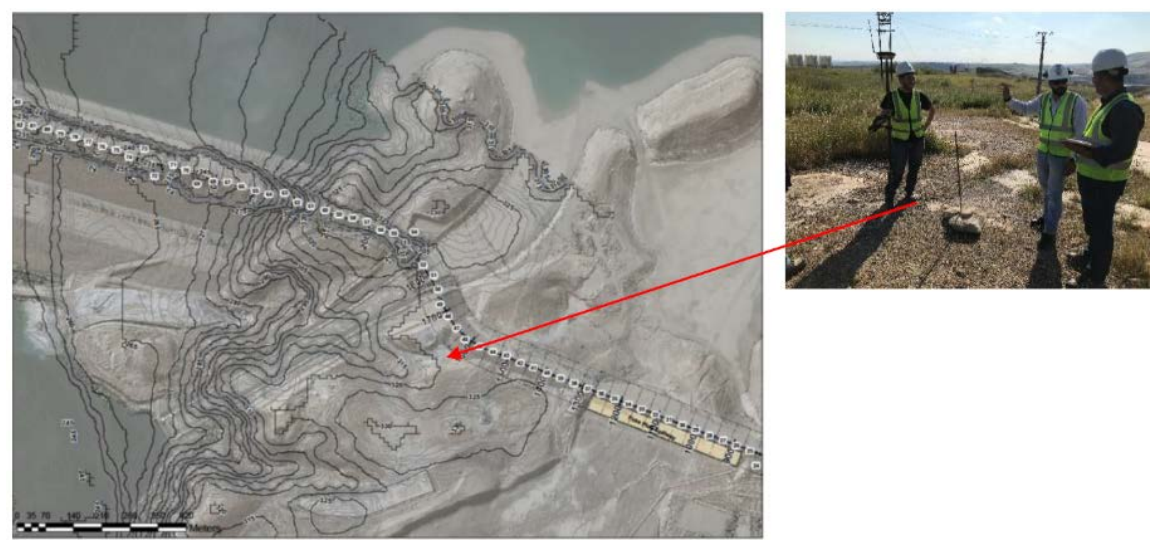

Figure 18. Location of point $\mathrm{Pz} 19$ - 1.

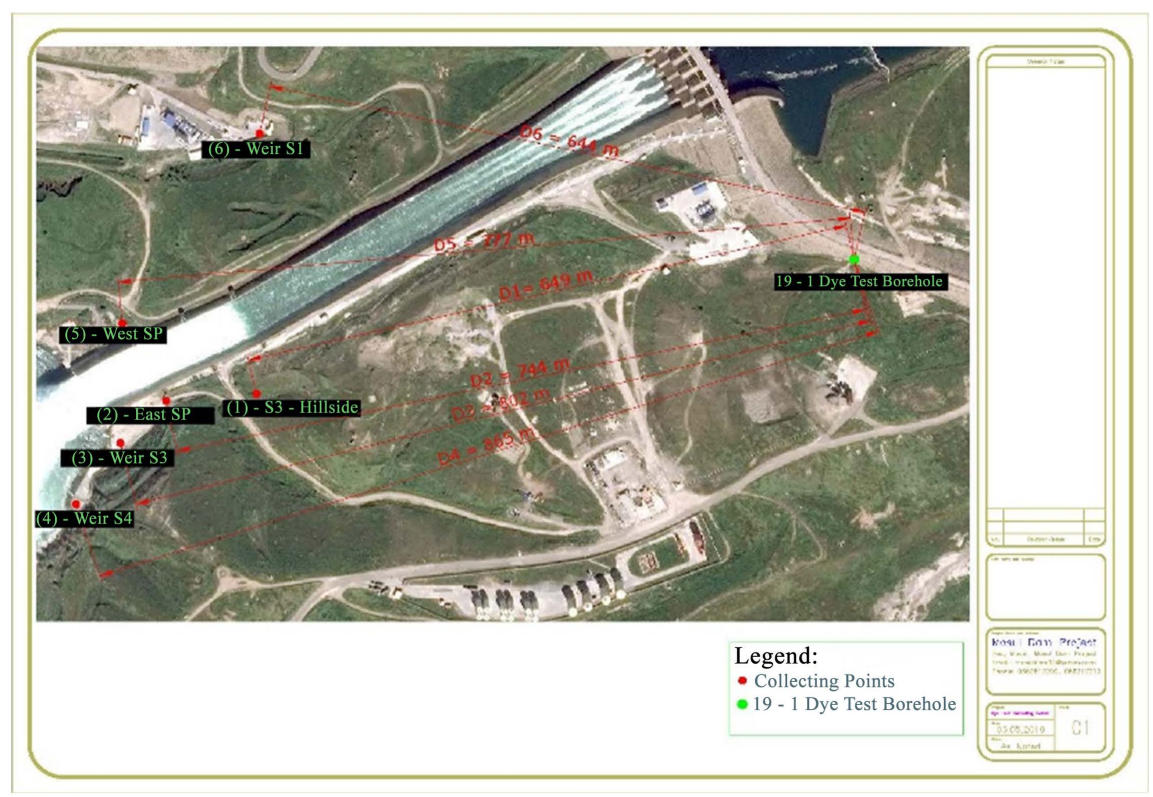

Figure 19. Points where dye was noticed after injection in $\mathrm{Pz} 19$.

Table 2. Dye test results during stage 2.

\begin{tabular}{ccc}
\hline Sample ID & Date & Dye Appear $(\mathrm{Y} / \mathrm{N})$ \\
\hline F-Bed & 12/May/19 15:56 & $\mathrm{N}$ \\
SP7 & 12/May/19 15:50 & $\mathrm{N}$ \\
A27 & 12/May/19 10:00 & $\mathrm{Y}$ \\
A50 & $12 /$ May/19 10:09 & $\mathrm{Y}$ \\
A53 & $12 /$ May/19 10:17 & $\mathrm{Y}$ \\
A55 & 12/May/19 10:52 & $\mathrm{N}$ \\
\hline
\end{tabular}

The green water was pumped into the F-Bed at 16S-U-P03 from 9:45 in the morning to 1:00 in the afternoon, for a total pumping time of 3 hours and 15 min. A total of 10,000 liters of dyed water was pumped in the F-Bed Aquifer. And the result is also positive in this test. Figure 24 shows the results of the test in the borehole. 


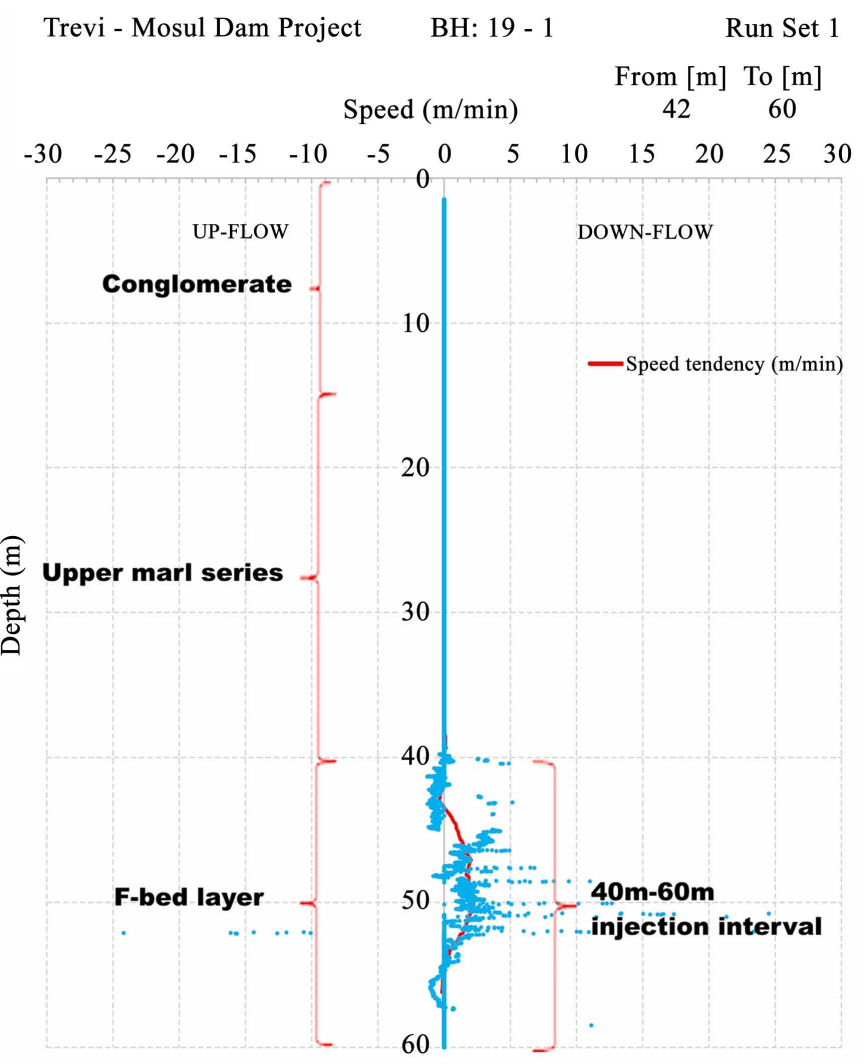

Figure 20. Flow speed of water within the piezometer during stage 1.

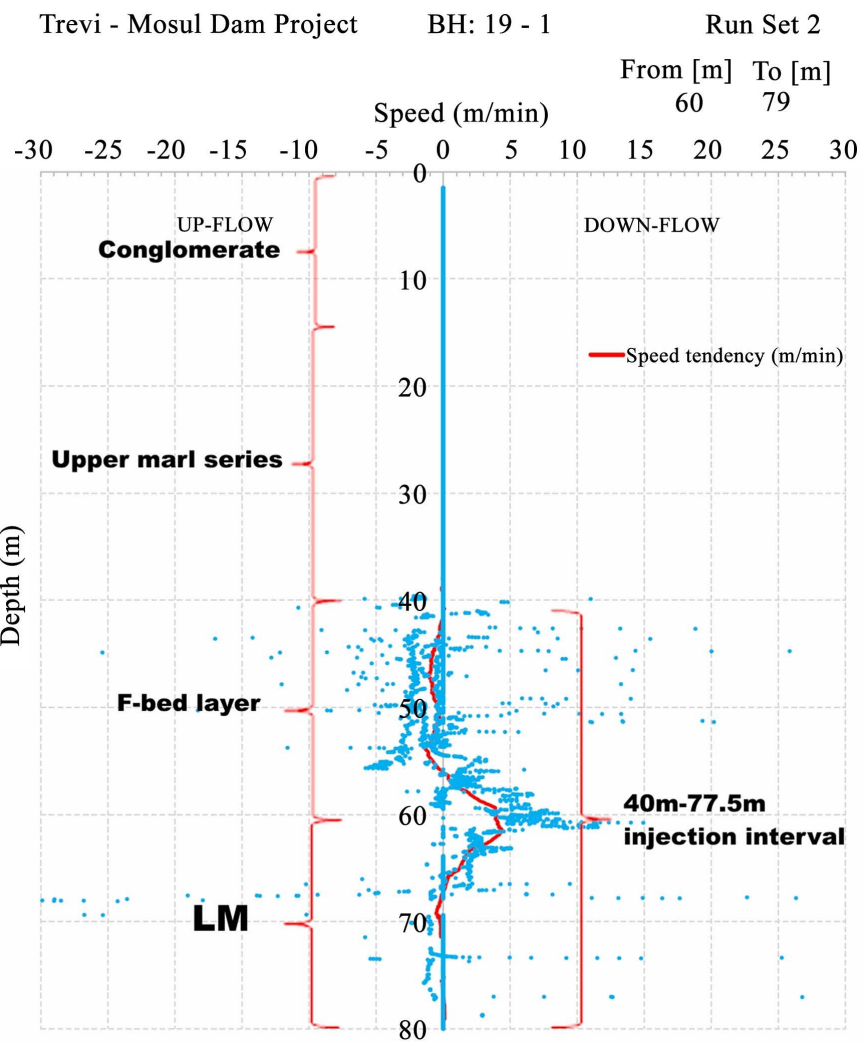

Figure 21. Flow within the lower marl series during stage 2 . 


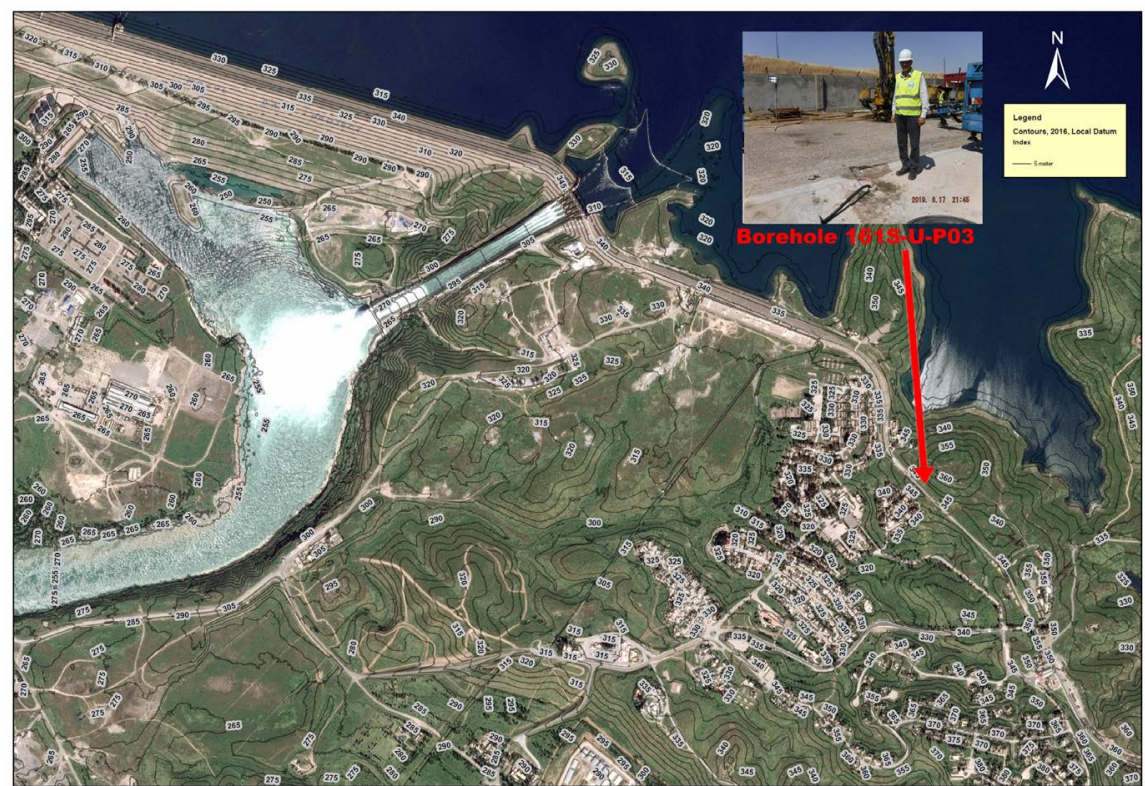

Figure 22. Location of 3.3 Piezometer 161S-U-P03.

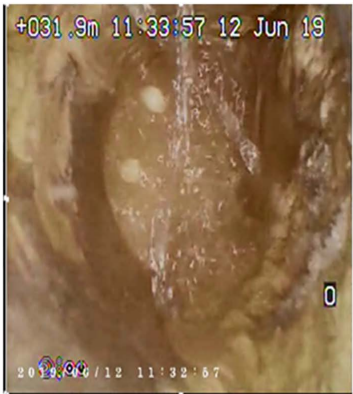

(a)

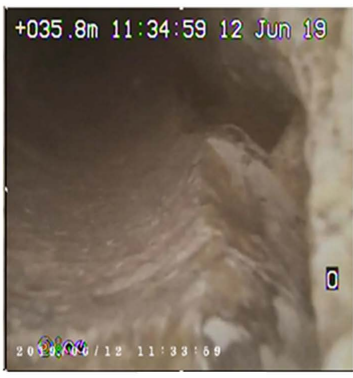

(c)

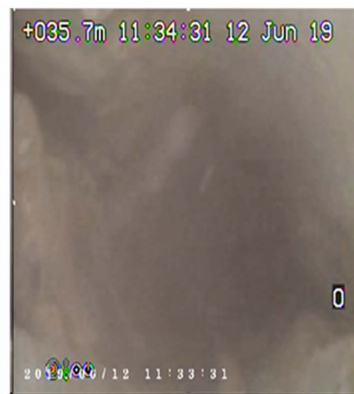

(b)

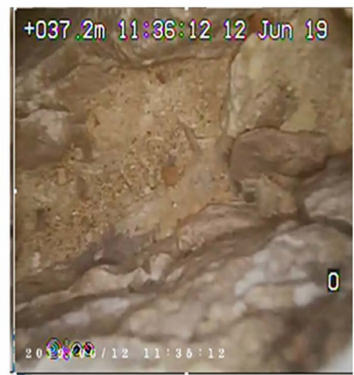

(d)

Figure 23. Photos taken by CCTV from the borehole.

\section{Discussion}

The dye test indicates that there is movement of ground water from left to right (east to west) on the downstream side, parallel to the dam body and along of the left (east) side wall of the spillway. The movement of water in left (east) side of the Dam is faster than predicted. From second dye test result the movement of the water under the spillway very slow, since the result of the Pz A55 from stage 2 show no green water, but when we get from the first hour of stage 3 it's shown 


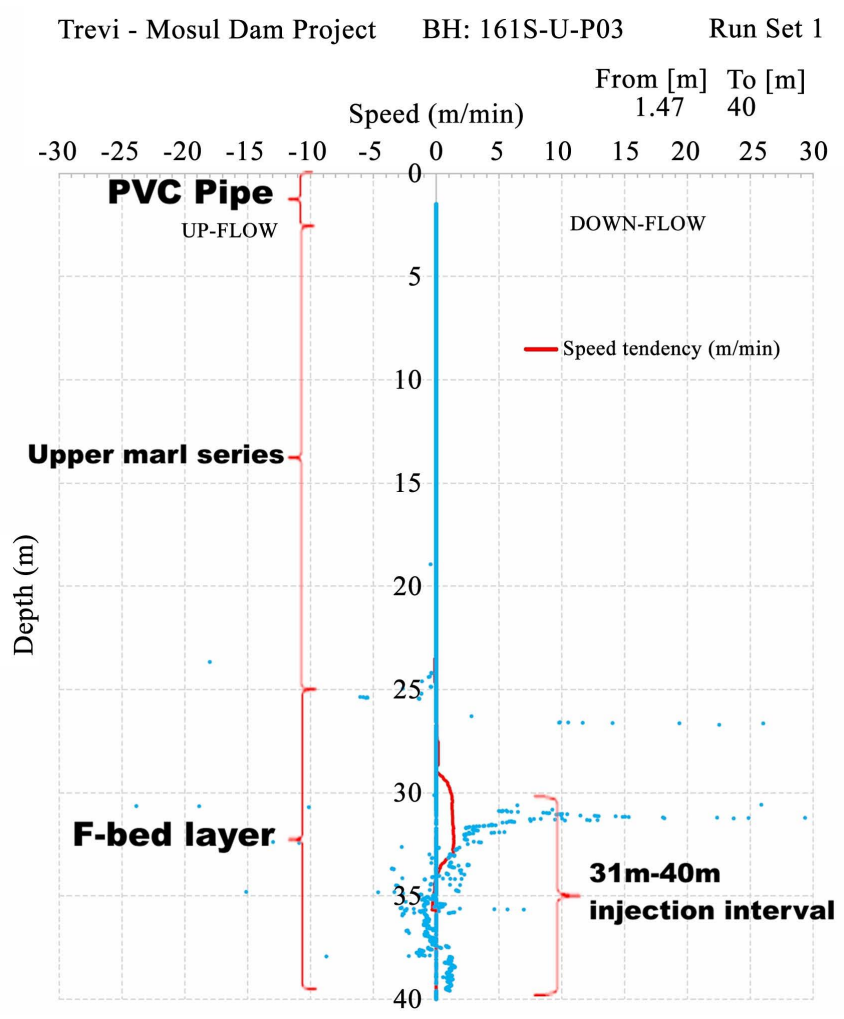

Figure 24. Flow within the lower marl series during stage 2.

green water. The lithology under the spillway is tight enough to slowdown the movement of the water, it takes about 4 days to travel from left (east) side to right (west) side, and about 1 month to reach cover dam No.6. Dye test with green dye observed in Weir 4 on April 12 from first dye test, two days after injection, but in the second and third test no dye was found in weir 3, weir 4, f-bed seep or LST1 \& LST2 seeps. This is opposite from what we expected from the geology layer and variation of the contour line in that area. The results show that both the F-Bed Limestone and Lower Marl Series Aquifers have a component of flow from the east hills to the large seeps near the Spillway. Almost all the water on the downstream piezometers is coming from the left (east). It appears that most of the downstream groundwater is not flowing across the grout curtain at the dam axis.

The results of the test for $\mathrm{Pz} 19$ - 1 indicate that there is movement of ground water from left to right (east to west) on the downstream side, parallel to the dam body and along of the left (east) side wall of the spillway. The movement of water in left (east) side of the spillway very fast related to the geology of left (east) side of the spillway. From the dye result, the movement of the water under the spillway is very slow. The lithology under the spillway is tight enough to slow down the movement of the water. It takes about 4 days to travel from left (east) side to right (west) side. No dye was found in weir 3, weir 4, f-bed or LS down, this is opposite what we expected from the geology layer and variation of the contour line in that area. 
Furthermore, the test on $\mathrm{Pz} 161$ indicates that there is movement of ground water from left to right (east to west) on the downstream side, parallel to the dam body and along of the left (east) side wall of the spillway. The movement of water in left (east) side of the dam is faster than predicted. No dye was found in weir 3, weir 4, f-bed seep or LST1 and LST2 seeps. This is opposite from what was expected from the geology and variation of the contour line in that area. Almost all the water on the downstream piezometers is coming from the left (east). It appears that most of the downstream groundwater is not flowing across the grout curtain at the dam axis.

\section{Conclusion}

Mosul Dam experienced plenty of problems since its operation in 1986. Due to the nature of the geological layers, which are mainly karistified and highly jointed limestone, gypsum and marls, there was seepage of water under the foundation of the dam due to the dissolution of 4 main gypsum beds. The Iraqi Ministry of Water Resources in cooperation with Trevi Company and US Army Corps of Engineers executed maintenance program. Within that program, grouting operations were done and highly advanced control program was set. In addition, local engineers were trained to carry out the operation and maintenance of the dam. One of the tests to monitor the seepage within the dam area is using the dye test. It seems that the situation is acceptable according to the dye test and the dam is safe in its present conditions. It is believed that this test should be performed on regular bases particularly when the water level is raised within the reservoir.

\section{Conflicts of Interest}

The authors declare no conflicts of interest regarding the publication of this paper.

\section{References}

[1] Abdullah, M., Al-Ansari, N. and Laue, J. (2019) Water Resources Projects: Large Storage Dams. Journal of Earth Sciences and Geotechnical Engineering, 9, 109-135.

[2] Abdullah, M., Al-Ansari, N. and Laue, J. (2019) Water Resources Projects in Iraq, Reservoirs in the Natural Depressions. Journal of Earth Sciences and Geotechnical Engineering, 9, 137-152.

[3] Abdullah, M., Al-Ansari, N. and Laue, J. (2019) Water Resources Projects in Iraq: Barrages. Journal of Earth Sciences and Geotechnical Engineering, 9, 153-167.

[4] Abdullah, M., Al-Ansari, N. and Laue, J. (2019) Water Resources Projects in Iraq, Irrigation Projects on Euphrates. Journal of Earth Sciences and Geotechnical Engineering, 9, 169-199.

[5] Abdullah, M., Al-Ansari, N. and Laue, J. (2019) Water Resources Projects in Iraq, Irrigation Projects on Tigris. Journal of Earth Sciences and Geotechnical Engineering, 9, 201-230.

[6] Abdullah, M., Al-Ansari, N. and Laue, J. (2019) Water Resources Projects in Iraq, 
Irrigation Projects on Tigris River Tributaries. Journal of Earth Sciences and Geotechnical Engineering, 9, 231-247.

[7] Abdullah, M., Al-Ansari, N. and Laue, J. (2019) Water Resources Projects in Iraq, Irrigation. Journal of Earth Sciences and Geotechnical Engineering, 9, 249-274.

[8] Abdullah, M., Al-Ansari, N. and Laue, J. (2019) Water Resources Projects in Iraq, Main Drains. Journal of Earth Sciences and Geotechnical Engineering, 9, 275-281.

[9] Abdullah, M., Al-Ansari, N. and Laue, J. (2019) Water Resources Projects in Iraq, Medium and Small Storage Dams. Journal of Earth Sciences and Geotechnical Engineering, 9, 283-289.

[10] Abdullah, M., Al-Ansari, N., Adamo, N., Sissakian, V. and Laue, J. (2020) Irrigation Major Systems on Euphrates River within Mesopotamia. Journal of Earth Sciences and Geotechnical Engineering, 10, 199-219.

[11] Abdullah, M. and Al-Ansari, N. (2021) Irrigation Projects in Iraq. Journal of Earth Sciences and Geotechnical Engineering, 11, 35-160.

https://doi.org/10.47260/jesge/1123

[12] Wakeley, L.D., Kelley, J.R., Talbot, C.A., Pearson, M.L. and Broadfoot, S.W. (2007) Geologic Conceptual Model of Mosul Dam. U.S. Army Engineer Research and Development Center, Vicksburg, 61 p. https://www.researchgate.net/publication/235070116 Geologic Conceptual Model of Mosul Dam

[13] Washington Group International, Black and Veatch, J.V. (2005) Mosul Dam Study. Final Report, Task Order No. 8, Republic of Iraq Project Contracting Office, Provisional Coalition Authority, Baghdad.

[14] Adamo, N., Al-Ansari, N.A., Sissakian, V., Knutsson, S. and Laue, J. (2018) Mosul Dam: Full Story. Dar Albasghaer Al-Islamiyah, Beruit, 351 p. (In Arabic)

[15] Sissakian, V.K. and Fouad, S.F. (2012) Geological Map of Iraq, Scale 1:1000000. 4th Edition, Iraq Geological Survey Publications, Baghdad. http://en.geosurviraq.iq/

[16] Sissakian, V., Al-Ansari, N.A., Issa, I.E., Adamo, N. and Knutsson, S. (2015) Mystery of Mosul Dam the Most Dangerous Dam in the World: General Geology. Journal of Earth Sciences and Geotechnical Engineering, 5, 1-13.

[17] Al-Ansari, N.A., Al-Jabbari, M., Barazachi, A. and Gayarah, A. (1984) Geological, Geophysical and Hydrological Investigation of Mosul Dam Area. Report Submitted to the Iraqi Ministry of Irrigation, Rusafa.

[18] Al-Ansari, N.A., Issa, I.E., Sissakian, V., Adamo, N. and Knutsson, S. (2015) Mystery of Mosul Dam the Most Dangerous Dam in the World: The Project. Journal of Earth Sciences and Geotechnical Engineering, 5, 15-31.

[19] Al-Ansari, N.A., Adamo, N., Issa, I.E., Sissakian, V. and Knutsson, S. (2015) Mystery of Mosul Dam the Most Dangerous Dam in the World: Karstification and Sinkholes. Journal of Earth Sciences and Geotechnical Engineering, 5, 33-45.

[20] IVO (Imatran Voima Osakeyhtio) (1969) Consulting Engineers, Finland, Geologic Map of Mosul Dam. Ministry of Agrarian Reform, Baghdad.

[21] Kelly, J., Wakeley, L.D., Broadfoot, S.W., Pearson, M.L., McGill, T.E., Jorgeson, J.D., Talbot, C.A. and McGrath, C.J. (2007) Geologic Setting of Mosul Dam and Its Engineering Implications. Final Report, U.S. Army Engineer District, Gulf Region, Baghdad.

[22] Al-Ansari, N., Adamo, N., Al-Hamdani, M.R., Sahar, K. and Al-Naemi, R.E.A. (2021) Mosul Dam Problem and Stability. Engineering, 13, 105-124. https://doi.org/10.4236/eng.2021.133009 
[23] Adamo, N., Al-Ansari, N.A., Laue, J., Knutsson, S. and Sissakian, V. (2017) Risk Management Concepts in Dam Safety Evaluation: Mosul Dam as a Case Study. Journal of Civil Engineering and Architecture, 11, 635-652. https://doi.org/10.17265/1934-7359/2017.07.002

[24] Adamo, N. and Al-Ansari, N.A. (2016) Mosul Dam Full Story: Engineering Problems. Journal of Earth Sciences and Geotechnical Engineering, 6, 213-244.

[25] Adamo, N. and Al-Ansari, N.A. (2016) Mosul Dam Full Story: Safety Evaluation of Mosul Dam. Journal of Earth Sciences and Geotechnical Engineering, 6, 185-212.

[26] Adamo, N., Al-Ansari, N.A., Issa, I.E., Sissakian, V. and Knutsson, S. (2015) Mystery of Mosul Dam the Most Dangerous Dam in the World: Problems Encountered During and after Impounding the Reservoir. Journal of Earth Sciences and Geotechnical Engineering, 5, 47-58.

[27] Adamo, N., Al-Ansari, N., Sissakian, V., Knutsson, S. and Laue, J. (2019) Mosul Dam: Geology and Safety Concerns. Journal of Civil Engineering and Architecture, 13, 151-177. https://doi.org/10.17265/1934-7359/2019.03.001

[28] Adamo, N., Al-Ansari, N.A., Knutsson, S., Laue, J. and Sissakian, S. (2017) Mosul Dam: A Catastrophe Yet to Unfold. Engineering, 9, 263-279.

https://doi.org/10.4236/eng.2017.93014

[29] Al-Ansari, N.A., Adamo, N., Sissakian, V., Knutsson, S. and Laue, J. (2017) Is Mosul Dam the Most Dangerous Dam in the World? Review of Previous Work and Possible Solutions. Engineering, 9, 801-823. https://doi.org/10.4236/eng.2017.910048

[30] Sissakian, V., Adamo, N. and Al-Ansari, N. (2020) The Role of Geological Investigations for Dam Siting: Mosul Dam a Case Study. Geotechnical and Geological Engineering, 38, 2085-2096. https://doi.org/10.1007/s10706-019-01150-2

[31] Sissakian, V., Adamao, N., Al-Ansari, N., Knutsson, S. and Laue, J. (2017) Defects in Foundation Design Due to Miss-Interpretation of the Geological Data. A Case Study of Mosul Dam. Engineering, 9, 683-702.

http://file.scirp.org/Html/5-8102857 78053.htm https://doi.org/10.4236/eng.2017.97042

[32] Sissakian, V., Al-Ansari, N.A. and Knutsson, S. (2014) Karstification Effect on the Stability of Mosul Dam and Its Assessment, North Iraq. Engineering, 6, 84-92. https://doi.org/10.4236/eng.2014.62012

[33] Al-Abayachi, S. (2016) Report on Mosul Dam, Iraqi House of Representatives. Agriculture, Water, and Marshes Sub-Committee, Baghdad.

[34] https://drive.google.com/file/d/0Byn0PFg9wZ5FNHNQUmxLb0JzenM/view

[35] Cetinic, F. (2016) Satellite Based Information to Support Health Analysis of Mosul Dam. International Workshop on Mosul Dam, Stockholm, 24-25 May 2016, 10 p.

[36] Milillo, P., Burgmann, R., Lundgren, P., Salzer, J., Perissin, D., Fielding, E., Biondi, F. and Milillo, G. (2016) Space Geodetic Monitoring of Engineered Structures: The Ongoing Destabilization of the Mosul Dam, Iraq. Scientific Reports, 6, Article No.37408. http://www.nature.com/articles/srep37408 https://doi.org/10.1038/srep37408

[37] Othman, A.A., Al-Maamar, A.F., Al-Manmi, D.A.M., Liesenberg, V., Hasan, S.E., Al-Saady, Y.I., Shihab, A.T. and Khwedim, K. (2019) Application of DInSAR-PSI Technology for Deformation Monitoring of the Mosul Dam, Iraq. Remote Sensing, 11, Article No. 2632. https://doi.org/10.3390/rs11222632

http://www.mdpi.com/journal/remotesensing

[38] Coffman, R. (2014) Mosul Dam Could Fail If ISIS Doesn't Continue Grouting Op- 
erations, Expert Says.

[39] MaCleanathan, J.T. (2009) Update for Screening Portfolio Risk Analysis for U.S. Army Corps of Engineers Dams. Risks and Reliability Directorate, U.S. Army Corps of Engineers, Washington DC.

[40] U.S. Department of the Interior Bureau of Reclamation (2014) Interim RCEM: Reclamation Consequence Estimating Methodology. Guidelines for Estimating Life Loss for Dam Safety Risk Analysis. United States Bureau of Reclamation, Washington DC. 